\title{
Improving Students' Reading Comprehension Text through Concept-Oriented Reading Instruction (CORI)
}

\author{
Dody Sugiarto ${ }^{1}$, Indrawati ${ }^{2}$, Rica Meygita ${ }^{3}$ \\ ${ }^{1}$ IAIN Syaikh Abdurrahman Siddik Bangka Belitung \\ ${ }^{2}$ IAIN Syaikh Abdurrahman Siddik Bangka Belitung \\ ${ }^{3}$ IAIN Syaikh Abdurrahman Siddik Bangka Belitung
}

\section{Keywords: \\ Reading Comprehension \\ CORI \\ Analytical Exposition Text}

\begin{abstract}
The aim of this research is to know the implementation of Concept-Oriented Reading Instruction (CORI) in improving students' reading comprehension of analytical exposition text and to find out whether there is a significant difference between students who were taught by using CORI and those who were not. This research used quantitative approach with experimental research which was conducted at an Islamic High School in Kemuja, Bangka Belitung Province. The researcher used purposive sampling technique and two classes were taken as the sample. The result of the test was analyzed by using statistical analysis of paired sample t-test and independent sample t-test. The result showed that the students who learned by using CORI got higher score than those who did not. It could be seen from the result of independent sample t-test of students' post-test between experimental group and control group, the t-obtained in equal variences assumed was 2.385, and the significant (2-tailed) was 0.023 . Since t-obtained was higher than t-table $(2.385>2.036)$ and the significant $(2$ tailed) was lower than computation with level significant $(0.023<0.05)$. Based on the fact above, it could be concluded that CORI significantly improved the students' reading comprehension.
\end{abstract}

Correspondence:

Dody Sugiarto,

Email: dodisg@gmail.com

\section{Introduction}

There are some reasons why reading skill should be learnt by the students. According to Dogan, reading is a social practice that is important for communication, for participating in life, and for understanding the world. Reading not only influences reading achievement but also increases general knowledge (DOĞAN, 2014).

Additionally, reading is a part of four skills in learning English. Many students get difficulties to study it. The obstacles may come from some factors, such as the ways of teaching, students' motivation, and the lack of awareness of how important reading is (Clarke, Truelove, Hulme, \& Snowling, 2013; Duke \& Pearson, 2009; Kendeou, Van Den Broek, Helder, \& Karlsson, 2014; Moreillon, 2007; Rayner, Pollatsek, Ashby, \& Clifton Jr, 2012; R. B. Ruddell \& Ruddell, 2004; Verhoeven \& Van Leeuwe, 2008). So, reading is a difficult skill to learn. It is the most crucial skill which must be mastered by students.

Based on preliminary research, the students got low score in reading analytical exposition text. However, in reality, some of the $11^{\text {th }}$ grade students of the high school found it difficult to comprehend the text. Moreover, by giving them a preliminary test, the researcher found that the students had low comprehension in reading analytical exposition text.

The problems faced by the students and the teacher were known in some indicators, as follows: based on the interview, the students were still confused with the meaning of vocabulary and present tense. That was the reason why they gave the answer perfunctorily. Based on the whole students' observation, the researcher found that students experienced difficulties in analytical exposition text features. They were still confused how to understand the vocabulary, simple present tense, and specific participants. They also found it difficult to comprehend analytical exposition text features, such as: generic structures. Moreover, students got difficulties to comprehend lexico grammatical features of analytical exposition texts. 
From the description above, the reseacher was interested in using an attractive teaching program. It is named Concept-Oriented Reading Instruction (CORI). Concept-Oriented Reading Instruction (CORI) is an instructional framework for content learning that combines all aspects of constructivist, integrated, interdisciplinary, and collaborative learning. It is a strategy developed by Guthrie, Alao, and Rinehart in 1997 (Guthrie, Alao, \& Rinehart, 1997). There are seven themes that comprise CORI: instruction those are Observational, Conceptual, Strategic, Self-directed, Collaborative, Self-expressive, and Coherent (M. R. Ruddell, 1997).

Moreover, Guthrie also selected strategies taught in the CORI model. They are activating background knowledge, questioning, searching for information, summarizing, and organizing graphically. The strategy of activating background knowledge refers to recalling experiences and knowledge of texts before reading, for the purpose of linking new content to prior understanding. Questioning refers to asking, or writing, a self-initiated question about the content of the text before reading. Searching for information refers to seeking and finding a subset of information in the total text by forming specific goals. The third one is summarizing. It refers to forming an accurate, abstract representaion of text after reading all or a substantial portion of material. The last one is organizing text graphically. It refers to constructing a spatial representation of the text based on knowledge, which may include drawings, concept maps, and diagrams (Wigfield, 2004).

The researcher thought this program could get good result in improving students' reading skill especially analytical exposition text. Moreover, CORI has simple procedures which consist of five majors, such as: the use of content goals for reading instruction, giving choice, using hands-on activities, using interesting, and organizing collaboration for learning from the text. There were some studies related to this research. Three of them were the research by Jaya and Marleni (Jaya \& Marleni, 2018), Azis (Azis \& Amri, 2015), and Sustika (Sustika, 2017).

Based on the results of those studies, it suggested that CORI was effective to improve student's reading comprehension of middle school and high school, as well as elementary (Guthrie, Mason-Singh, \& Coddington, 2012; Kalsum, Suwarno, \& Dharmayana, 2017; Suryani, 2017; Wigfield, Mason-Singh, Ho, \& Guthrie, 2014). In this research, the researcher tried to conduct a study entitled, "Improving Students' Reading Comprehension in Analytical Exposition Text through Concept-Oriented Reading Instruction (CORI) to $11^{\text {th }}$ Grade Students of MA Al-Islam Kemuja". This research was conducted to describe the implementation and to find out whether there is a significant difference of results between the two groups of sample.

\section{Methods}

This research used quasi-experimental design. It was type of experimental that the researcher limits the control the selection of participants. The type of this quasi-experiment was non-randomized control group pre-test and post-test designs. It means the control group was selected without randomization. In addition, the experimental group used treatment, while the control group received no particular treatment (Ary, Jacobs, Irvine, \& Walker, 2018; Levy \& Ellis, 2011)

The researcher conducted the research by using one of the quasi-experimental designs: pre-test and posttest non-equivalent control group design. In the experimental group, the researcher taught the students by using CORI development, while in the control group the reseacher taught by using non-CORI development.

The population in this study was all of the $11^{\text {th }}$ grade students of MA Al-Islam Kemuja with total number of students 114. Researcher used purposive sampling as the technique sampling of the research. The researcher took two classes of the population as the samples of this research. Class XI MAK 2 was experimental class, while XI MAK 1 was control class.

In this study, the researcher used three instruments to collect the data, they are test, observation, and documentation. Test was analyzed by statistical analysis while data from observation and documentation were analyzed by non-statistical analysis. Then, the statistical data was measured by using SPSS 17.0 and non-statistical data was analyzed by descriptive analysis.

The students' reading analytical exposition text was designed to cover a range of subskills. It was scored in term of five elements: using vocabulary knowledge, finding main idea, making inference, generic structure, and lexico-grammatical features. Using vocabulary knowledge was concerned with the meaning of an unknown word; generic structure referred to the parts of analytical exposition text, and lexicogrammatical features was concerned with the grammar and word order. In the technique of data analysis, the researcher used SPSS 17.0 in calculating the data. The statistical strategy which is used by researcher 
was independent sample t-test. This strategy was used to compare the result of pre-test and post-test between experiment and control group.

According to Babbie, t-test is used to compare the results of two groups (statistical significance of differences in groups' means) (Babbie, 2015). It means, in this research, t-test is used to compare the results of pre-test and post-test between experimental and control group. Therefore, it is used to know whether there is a significant difference between the students' pre-test score and their post-test score.

\section{Results and Discussions}

The researcher conducted this research for twelve meetings. It took around two months in 2019 . First meeting was used to give pre-test and the last meeting was used for post-test. Then, the reseacher applied CORI for ten meetings. It is used to know whether the implementation of CORI was effective or not for improving students' reading comprehension in analytical exposition text.

The Interpretation of this study consisted of two parts, they were the discussion of the implementation and observation and the discussion of analytical analysis.

1. The Analysis of the Implementation and Observation

After accomplishing the implementation and observation in this study, the researcher could interpret that the process of teaching and learning in improving students' reading comprehension on analytical exposition text through Concept-Oriented Reading Instruction (CORI) was effective. It could be proved by the results of observation during implementing CORI in the classroom that can be seen below:

Table 1

The Results of Observation

\begin{tabular}{|c|c|c|c|c|c|c|c|c|c|c|c|}
\hline \multirow[b]{2}{*}{ 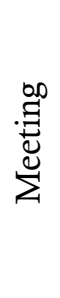 } & \multirow[b]{2}{*}{ 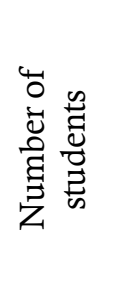 } & \multicolumn{3}{|c|}{ Participation } & \multicolumn{3}{|c|}{ Cooperation } & \multicolumn{4}{|c|}{ Concept } \\
\hline & & 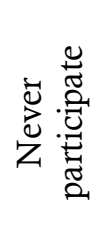 & 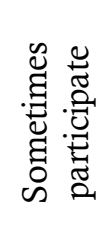 & 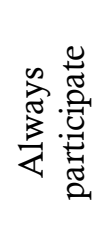 & 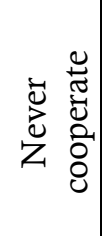 & 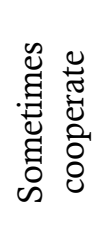 & 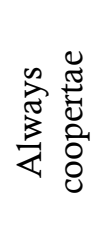 & 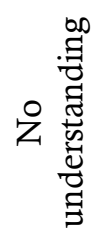 & 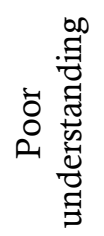 & 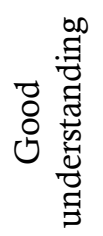 & 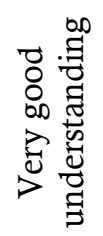 \\
\hline 3 & $\begin{array}{c}15 \\
(88 \%)\end{array}$ & $\begin{array}{c}0 \\
(0 \%)\end{array}$ & $\begin{array}{c}10 \\
(58 \%)\end{array}$ & $\begin{array}{c}5 \\
(29 \%)\end{array}$ & $\begin{array}{c}0 \\
(0 \%)\end{array}$ & $\begin{array}{c}4 \\
(23 \%)\end{array}$ & $\begin{array}{c}11 \\
(64 \%)\end{array}$ & $\begin{array}{c}2 \\
(11 \%)\end{array}$ & $\begin{array}{c}7 \\
(41 \%)\end{array}$ & $\begin{array}{c}6 \\
(35 \%)\end{array}$ & $\begin{array}{c}0 \\
(0 \%)\end{array}$ \\
\hline 4 & $\begin{array}{c}17 \\
(100 \%)\end{array}$ & $\begin{array}{c}0 \\
(0 \%)\end{array}$ & $\begin{array}{c}9 \\
(52 \%)\end{array}$ & $\begin{array}{c}8 \\
(47 \%)\end{array}$ & $\begin{array}{c}0 \\
(0 \%)\end{array}$ & $\begin{array}{c}6 \\
(35 \%)\end{array}$ & $\begin{array}{c}11 \\
(64 \%)\end{array}$ & $\begin{array}{c}0 \\
(0 \%)\end{array}$ & $\begin{array}{c}4 \\
(23 \%)\end{array}$ & $\begin{array}{c}11 \\
(64 \%)\end{array}$ & $\begin{array}{c}2 \\
(11 \%)\end{array}$ \\
\hline 5 & $\begin{array}{c}16 \\
(94 \%)\end{array}$ & $\begin{array}{c}0 \\
(0 \%)\end{array}$ & $\begin{array}{c}11 \\
(64 \%)\end{array}$ & $\begin{array}{c}5 \\
(29 \%)\end{array}$ & $\begin{array}{c}0 \\
(0 \%)\end{array}$ & $\begin{array}{c}5 \\
(29 \%) \\
\end{array}$ & $\begin{array}{c}11 \\
(64 \%)\end{array}$ & $\begin{array}{c}0 \\
(0 \%)\end{array}$ & $\begin{array}{c}1 \\
(5 \%)\end{array}$ & $\begin{array}{c}11 \\
(64 \%)\end{array}$ & $\begin{array}{c}4 \\
(23 \%)\end{array}$ \\
\hline 6 & $\begin{array}{c}17 \\
(100 \%)\end{array}$ & $\begin{array}{c}0 \\
(0 \%)\end{array}$ & $\begin{array}{c}9 \\
(52 \%)\end{array}$ & $\begin{array}{c}8 \\
(47 \%)\end{array}$ & $\begin{array}{c}0 \\
(0 \%)\end{array}$ & $\begin{array}{c}6 \\
(35 \%)\end{array}$ & $\begin{array}{c}11 \\
(64 \%)\end{array}$ & $\begin{array}{c}0 \\
(0 \%)\end{array}$ & $\begin{array}{c}1 \\
(5 \%)\end{array}$ & $\begin{array}{c}9 \\
(52 \%)\end{array}$ & $\begin{array}{c}7 \\
(41 \%)\end{array}$ \\
\hline 7 & $\begin{array}{c}17 \\
(100 \%)\end{array}$ & $\begin{array}{c}0 \\
(0 \%)\end{array}$ & $\begin{array}{c}9 \\
(52 \%)\end{array}$ & $\begin{array}{c}8 \\
(47 \%)\end{array}$ & $\begin{array}{c}0 \\
(0 \%)\end{array}$ & $\begin{array}{c}9 \\
(52 \%)\end{array}$ & $\begin{array}{c}8 \\
(47 \%)\end{array}$ & $\begin{array}{c}0 \\
(0 \%)\end{array}$ & $\begin{array}{c}1 \\
(5 \%)\end{array}$ & $\begin{array}{c}8 \\
(47 \%)\end{array}$ & $\begin{array}{c}8 \\
(47 \%)\end{array}$ \\
\hline 8 & $\begin{array}{c}17 \\
(100 \%)\end{array}$ & $\begin{array}{c}0 \\
(0 \%)\end{array}$ & $\begin{array}{c}7 \\
(41 \%)\end{array}$ & $\begin{array}{c}10 \\
(58 \%)\end{array}$ & $\begin{array}{c}0 \\
(0 \%)\end{array}$ & $\begin{array}{c}6 \\
(35 \%)\end{array}$ & $\begin{array}{c}11 \\
(64 \%)\end{array}$ & $\begin{array}{c}0 \\
(0 \%)\end{array}$ & $\begin{array}{c}1 \\
(5 \%)\end{array}$ & $\begin{array}{c}7 \\
(41 \%)\end{array}$ & $\begin{array}{c}9 \\
(52 \%)\end{array}$ \\
\hline 9 & $\begin{array}{c}17 \\
(100 \%)\end{array}$ & $\begin{array}{c}0 \\
(0 \%)\end{array}$ & $\begin{array}{c}10 \\
(58 \%)\end{array}$ & $\begin{array}{c}7 \\
(41 \%)\end{array}$ & $\begin{array}{c}1 \\
(5 \%)\end{array}$ & $\begin{array}{c}6 \\
(35 \%)\end{array}$ & $\begin{array}{c}10 \\
(58 \%)\end{array}$ & $\begin{array}{c}0 \\
(0 \%)\end{array}$ & $\begin{array}{c}6 \\
(35 \%)\end{array}$ & $\begin{array}{c}0 \\
(0 \%)\end{array}$ & $\begin{array}{c}11 \\
(64 \%)\end{array}$ \\
\hline 10 & $\begin{array}{c}17 \\
(100 \%)\end{array}$ & $\begin{array}{c}0 \\
(0 \%)\end{array}$ & $\begin{array}{c}8 \\
(47 \%) \\
\end{array}$ & $\begin{array}{c}9 \\
(52 \%) \\
\end{array}$ & $\begin{array}{c}0 \\
(0 \%) \\
\end{array}$ & $\begin{array}{c}7 \\
(41 \%) \\
\end{array}$ & $\begin{array}{c}10 \\
(58 \%)\end{array}$ & $\begin{array}{c}0 \\
(0 \%)\end{array}$ & $\begin{array}{c}0 \\
(0 \%)\end{array}$ & $\begin{array}{c}2 \\
(11 \%)\end{array}$ & $\begin{array}{c}15 \\
(88 \%) \\
\end{array}$ \\
\hline 11 & $\begin{array}{c}17 \\
(100 \%)\end{array}$ & $\begin{array}{c}3 \\
(17 \%)\end{array}$ & $\begin{array}{c}6 \\
(35 \%)\end{array}$ & $\begin{array}{c}8 \\
(47 \%)\end{array}$ & $\begin{array}{c}0 \\
(0 \%)\end{array}$ & $\begin{array}{c}5 \\
(29 \%)\end{array}$ & $\begin{array}{c}12 \\
(70 \%)\end{array}$ & $\begin{array}{c}0 \\
(0 \%)\end{array}$ & $\begin{array}{c}0 \\
(0 \%)\end{array}$ & $\begin{array}{c}3 \\
(17 \%)\end{array}$ & $\begin{array}{c}14 \\
(82 \%)\end{array}$ \\
\hline
\end{tabular}

When the researcher applied CORI in experimental group, the students enjoyed the process of teaching and learning. They were interested in knowing the text, it could be seen from the first procedure of CORI was applied where the reseacher asked them to choose which text that they wanted to learn first. They felt very excited to choose the text. Then, the next steps of CORI were followed by the students effectively. 
In term of students' cooperation aspect in group, from the second until the ninth meeting, it was divided into two types of cooperation. The first one was the students always cooperated with his/her group members and the second was they sometimes cooperated with his/her friends in group. During the treatment in the classroom, the students could work together and followed the steps of CORI very well. Each member had part of their own job, for the example in comprehending the text, they said each paragraph would be comprehended by each member. So, all members was able to work well. Then, after that was done, they shared the information of what they got. While, for the tenth meeting, the researcher gave the quiz which consisted of twenty questions to the students. There was no cooperation among the students because they should answer the quiz individually. After that, they discussed the results of the quiz together. In addition, the student's cooperation was good in doing their jobs.

As the result, the students' concept in reading analytical exposition text got improvement through CORI. It could be seen from the results of product of observation sheet. Most of students got increasing score during implementing the procedures of CORI. Actually, they have had good understanding in English because they should use three languages including English in Islamic boarding school. It means that they have known the basic of English. In the second meeting up to ninth meeting, some of students had a very good understanding in reading analytical exposition text, most of students had good understanding, and a few of students had poor understanding. Of course, the students' concept was good in doing their job. Moreover, by using CORI, they were supposed to be more understanding than before especially in reading analytical exposition text.

Furthermore, the students' participation in group work was good as well. Based on the results of observation sheet, from the second until the ninth meeting, most of them always participate actively in discussion and only some of the students sometime participate actively in discussion. Then, they could interact well and shared their thoughts effectively to their group. In addition, the students' participation in the class during implementing the CORI was good.

Besides, the researcher got some drawbacks during teaching and learning process. Although CORI was effective to improve students' reading comprehension, but the researcher had some difficulties, they were the class become noisy in group work, the students might not use electronical dictionary like smartphone or alfalink, female students might not join male students, and some male students were too slow to move when the reseacher asked them to join their group. However, from the researcher explanation step by step and the procedures of CORI, they could improve their reading and understand the text.

From the explanation above, the researcher concluded that CORI could be one of choices to teach reading comprehension. It was effective to be implemented in the classroom. It could improve students' reading comprehension especially in analytical exposition text.

\section{The Interpretation of Statistical Analysis Result}

After implementing the CORI in teaching reading to the eleventh grade students of MA Al-Islam Kemuja, the researcher concluded that CORI was effective to improve students' reading comprehension in analytical exposition text. The researcher interpreted that there was a significant difference in reading comprehension between the students who were taught by using CORI and students who were taught by using non-CORI. It could be proved by the following explanation.

a. The Comparison between Experimental Group and Control Group

Table 4

Comparison between Experimental Group and Control Group

\begin{tabular}{|c|c|c|c|c|c|c|}
\hline \multirow[b]{2}{*}{ Groups } & \multicolumn{2}{|l|}{ Pre-test } & \multicolumn{2}{|l|}{ Post-test } & \multirow{2}{*}{$\begin{array}{l}\text { Mean } \\
\text { of Pre- } \\
\text { test }\end{array}$} & \multirow{2}{*}{$\begin{array}{l}\text { Mean } \\
\text { of } \\
\text { Post- } \\
\text { test }\end{array}$} \\
\hline & Highest & Lowest & Highest & Lowest & & \\
\hline $\begin{array}{l}\text { Experimental } \\
\text { Group }\end{array}$ & 39 & 8 & 96 & 46 & 24.29 & 83.82 \\
\hline $\begin{array}{l}\text { Control } \\
\text { Group }\end{array}$ & 39 & 8 & 89 & 50 & 25.94 & 75.18 \\
\hline
\end{tabular}

Based on the table above, both experimental and control group got the same highest and lowest score of pre-test, they were 39 and 8 . Then, the highest post-test in experimental group was 96 and the lowest was 46 . While in control group, the highest score of post-test was 89 and the lowest was 
50. Furthermore, the mean of pre-test in experimental group was 24.29 and the mean of post-test was 83.82. Meanwhile, the mean of pre-test in control group was 25.94 and the mean of post-test was 75.18. It showed that both experimental and control group got improvement. However, the experimental group got more improvements than the control group. It could be seen from the mean of pre-test and post-test. In the experimental group, the mean of pre-test was lower than the mean of the control group. Then, in the post-test score, the experimental group got higher mean than the control group.

b. Statistical Analysis Students' Pre-test between Experimental Group and Control Group

Table 5

Group Statistics Independent Sample t-test in Pre-test

\begin{tabular}{|c|c|c|c|c|c|}
\hline \multicolumn{6}{|c|}{ Group Statistics } \\
\hline & Group & $\mathrm{N}$ & $\begin{array}{c}\text { Mea } \\
\mathrm{n}\end{array}$ & $\begin{array}{c}\text { Std. } \\
\text { Deviatio } \\
\mathrm{n}\end{array}$ & $\begin{array}{l}\text { Std. } \\
\text { Error } \\
\text { Mean }\end{array}$ \\
\hline \multirow{2}{*}{$\begin{array}{l}\text { Scores of } \\
\text { Reading } \\
\text { Comprehension } \\
\text { Pre-Test }\end{array}$} & $\begin{array}{l}\text { Experimental } \\
\text { Group }\end{array}$ & 17 & 24.29 & 9.047 & 2.194 \\
\hline & $\begin{array}{l}\text { Control } \\
\text { Group }\end{array}$ & 17 & 25.94 & 8.996 & 2.182 \\
\hline
\end{tabular}

Based on group statistics of independent sample t-test on pre-test above, it showed that both experimental and control group consisted of 17 students. Then, the mean of pre-test in experimental group was 24.29 , the standard deviation was 9.047 , and the standard error mean was 2.194, while the mean of control group was 25.94, the standard deviation was 8.996, and standard error mean was 2.182 . 
Table 6

Independent Sample t-test in Pre-test

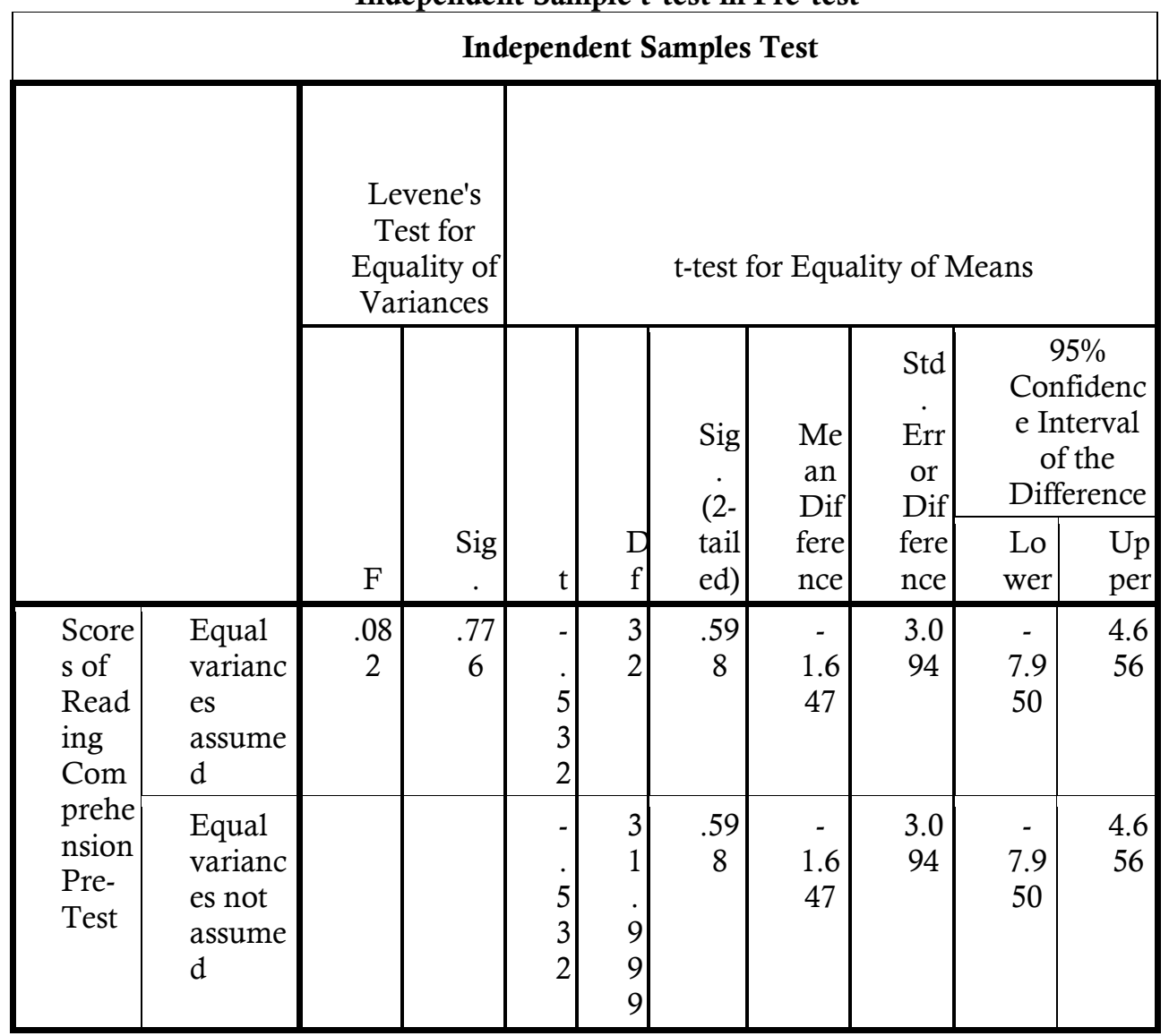

The result of independent sample t-test in the table above, it showed that the mean difference between pre-test in experimental and control group was 1.647, the standard error was 3.094, the significant (two tailed) was 0.598 , t-obtained was 0.532 , degree of freedom was 32 , and critical value of t-table was 2.036. Based on the table, t-obtained 0.532 was lower than critical value of t-table 2.036 and the significant (two tailed) 0.598 was higher than computation with level significant 0.05 . It meant there was no significant difference in pre-test between experimental and control group.

c. Statistical Analysis Students' Post-test between Experimental Group and Control Group

Table 7

Group Statistics Independent Sample t-test in Post-Test

\begin{tabular}{|c|c|c|c|c|c|}
\hline \multicolumn{6}{|c|}{ Group Statistics } \\
\hline & Group & $\mathrm{N}$ & $\begin{array}{c}\text { Mea } \\
\mathrm{n}\end{array}$ & $\begin{array}{c}\text { Std. } \\
\text { Deviatio } \\
\mathrm{n}\end{array}$ & $\begin{array}{l}\text { Std. } \\
\text { Error } \\
\text { Mean }\end{array}$ \\
\hline \multirow{2}{*}{$\begin{array}{l}\text { Scores of Reading } \\
\text { Comprehension } \\
\text { Post-Test }\end{array}$} & $\begin{array}{l}\text { Experiment } \\
\text { al Group }\end{array}$ & 17 & 83.82 & 11.849 & 2.874 \\
\hline & $\begin{array}{l}\text { Control } \\
\text { Group }\end{array}$ & 17 & 75.18 & 9.112 & 2.210 \\
\hline
\end{tabular}


Based on group statistics of independent sample t-test on post-test above, it showed that both experimental and control group consisted of 17 students. Then, the mean of post-test in experimental group was 83.82 , the standard deviation was 11.849 , and the standard error mean was 2.874 , while the mean of control group was 75.18 , the standard deviation was 9.112, and standard error mean was 2.210 .

Table 8

Independent Sample t-test in Post-test

\begin{tabular}{|c|c|c|c|c|c|c|c|c|c|c|}
\hline \multicolumn{11}{|c|}{ Independent Samples Test } \\
\hline & & \multicolumn{2}{|c|}{$\begin{array}{c}\text { Levene's } \\
\text { Test for } \\
\text { Equality } \\
\text { of } \\
\text { Variances }\end{array}$} & \multicolumn{7}{|c|}{ t-test for Equality of Means } \\
\hline & & & & & & \multirow{2}{*}{$\begin{array}{l}\text { Sig } \\
\dot{(2-} \\
\text { tail } \\
\text { ed) }\end{array}$} & \multirow{2}{*}{$\begin{array}{c}\text { Me } \\
\text { an } \\
\text { Dif } \\
\text { fere } \\
\text { nce }\end{array}$} & \multirow{2}{*}{$\begin{array}{l}\text { Std. } \\
\text { Err } \\
\text { or } \\
\text { Diff } \\
\text { ere } \\
\text { nce }\end{array}$} & \multicolumn{2}{|c|}{$\begin{array}{c}95 \% \\
\text { Confidence } \\
\text { Interval of } \\
\text { the } \\
\text { Difference }\end{array}$} \\
\hline & & $\mathrm{F}$ & Sig. & $\mathrm{T}$ & $\begin{array}{l}\mathrm{D} \\
\mathrm{f}\end{array}$ & & & & $\begin{array}{l}\text { Lo } \\
\text { wer }\end{array}$ & $\begin{array}{l}\text { Up } \\
\text { per }\end{array}$ \\
\hline \multirow{2}{*}{$\begin{array}{l}\text { Score } \\
\text { s of } \\
\text { Read } \\
\text { ing } \\
\text { Com } \\
\text { prehe } \\
\text { nsion } \\
\text { Post- } \\
\text { Test }\end{array}$} & $\begin{array}{l}\text { Equal } \\
\text { varianc } \\
\text { es } \\
\text { assume } \\
\text { d }\end{array}$ & $\begin{array}{l}.5 \\
6 \\
4\end{array}$ & $\begin{array}{c}.45 \\
8\end{array}$ & $\begin{array}{l}2 \\
\dot{3} \\
8 \\
5\end{array}$ & $\begin{array}{l}3 \\
2\end{array}$ & $\begin{array}{c}.02 \\
3\end{array}$ & $\begin{array}{c}8.6 \\
47\end{array}$ & $\begin{array}{l}3.6 \\
25\end{array}$ & $\begin{array}{l}1.2 \\
62\end{array}$ & $\begin{array}{c}16 . \\
032\end{array}$ \\
\hline & $\begin{array}{l}\text { Equal } \\
\text { varianc } \\
\text { es not } \\
\text { assume } \\
\text { d }\end{array}$ & & & $\begin{array}{l}2 \\
\dot{3} \\
8 \\
5\end{array}$ & $\begin{array}{l}3 \\
0 \\
. \\
0 \\
2 \\
0\end{array}$ & $\begin{array}{c}.02 \\
4\end{array}$ & $\begin{array}{c}8.6 \\
47\end{array}$ & $\begin{array}{l}3.6 \\
25\end{array}$ & $\begin{array}{l}1.2 \\
43\end{array}$ & $\begin{array}{c}16 . \\
051\end{array}$ \\
\hline
\end{tabular}

The result of independent sample t-test in the table above, it showed that the mean difference between post-test in experimental and control group was 8.647, the standard error difference was 3.625 , the significant (two tailed) of equal variances assumed and equal variances not assumed were 0.023 and 0.024 . Next, t-obtained was 2.385 , degree of freedom of equal variances assumed and equal variances not assumed were 32 and 30 , then critical value of t-table was 2.036. Based on the table, tobtained 2.385 was higher than critical value of t-table 2.036 and both the significant (two tailed) of equal variances assumed and equal variances not assumed 0.023 and 0.024 were lower than computation with level significant 0.05 .

Therefore, it could be stated that there was a significant difference between students who were taught through CORI and who were taught without using CORI. It meant that the alternative hypothesis $(\mathrm{Ha})$ was accepted, while the null hypothesis $(\mathrm{Ho})$ was rejected. From the explanation above, the researcher got a real fact that the theory of CORI was effective to improve students' reading comprehension.

This research limited by six materials, they were social function, generic structures, language features, main idea, making inferences, and vocabulary knowledge. Based on the result of post-test in experimental and control group, the students understood the language features well, the second was 
social function, the third was generic structures, the fourth was main idea, the fifth was making inference, and the eighth was vocabulary knowledge.

\section{Conclusions}

The research had acquired quantitative data related to the use of CORI in improving reading comprehension of grade XI students of high school in Bangka. It could be concluded that the use of CORI was believed to be effective in improving the students' reading comprehension.

CORI helped the students in reading to comprehend the analytical exposition text easily. Moreover, it helped them understanding the generic structures, lexico-grammatical features, social function of analytical exposition text and helped them answer the questions which were related to the analytical exposition text easier than before. During the meetings, they also showed positive responses toward the teaching and learning process. They looked more serious in the teaching learning process as well. Besides that, they enjoyed the implementation of CORI in the classroom.

Moreover, there was a significant difference in reading comprehension between experimental group and control group, and it can be seen from the following explanation. Firstly, based on the results of pre-test and post-test in experimental and control group. The researcher compared that the scores of pre-test and post-test in experimental group got higher score than control group. Experimental group was a group of students were taught by using CORI. The lowest score of pre-test in experimental group was 8 and the highest was 39. Then, the mean of pre-test in experimental group was 24.29. And then, the lowest score of post-test was 46 and the highest was 96 . Then, the mean of post-test was 83.82 . Therefore, the researcher concluded that the scores of the students in experimental group were increased.

In the control group, the lowest score of pre-test was 8 and the highest was 39. Meanwhile, based on the scores of post-test in control group, the lowest score was 50 and the highest was 89 . In addition, the mean of pre-test in control group was 25.94 and the mean of post-test was 75.18 . Therefore, the researcher concluded that the scores of all students in control group were increased as well.

Furthermore, based on the result of independent sample t-test, it showed that the mean difference between post-test in experimental and control group was 8.647, the standard error difference was 3.625, the significant (two tailed) of equal variances assumed and equal variances not assumed were 0.023 and 0.024 . Next, the value of t-obtained was 2.385 , degree of freedom of equal variances assumed and equal variances not assumed were 32 and 30 , then critical value of t-table was 2.036. Based on the table, t-obtained 2.385 was higher than critical value of t-table 2.036 and both the significant (two tailed) of equal variances assumed and equal variances not assumed 0.023 and 0.024 were lower than computation with level significant 0.05 .

It means the null hypothesis $\left(\mathrm{H}_{0}\right)$ was rejected and the alternative hypothesis $\left(\mathrm{H}_{\mathrm{a}}\right)$ was accepted. Based on the fact above, it could be concluded that there was a significant difference between the students who were taught through CORI and who were taught through non-CORI in the eleventh grade students of high school in Bangka. In other words, using this strategy can be an effective option for teachers, especially in high schools.

\section{References}

Ary, D., Jacobs, L. C., Irvine, C. K. S., \& Walker, D. (2018). Introduction to research in education. Cengage Learning.

Azis, A., \& Amri, Z. (2015). The use of Concept-Oriented Reading Instruction (CORI) to improve teaching and learning of reading narrative texts to grade VIII-B students of SMP Islamic Center Siak. English Language Teaching (ELT), 3(1).

Babbie, E. R. (2015). The practice of social research. Nelson Education.

Clarke, P. J., Truelove, E., Hulme, C., \& Snowling, M. J. (2013). Developing reading comprehension (Vol. 1). Wiley Online Library.

DOĞAN, B. (2014). Prospective Teachers' Reasons: The Importance of Reading a Book. Information 
World/Bilgi Dunyasi, 15(1).

Duke, N. K., \& Pearson, P. D. (2009). Effective practices for developing reading comprehension. Journal of Education, 189(1-2), 107-122.

Guthrie, J. T., Alao, S., \& Rinehart, J. M. (1997). Literacy issues in focus: Engagement in reading for young adolescents. Journal of Adolescent \& Adult Literacy, 40(6), 438-446.

Guthrie, J. T., Mason-Singh, A., \& Coddington, C. S. (2012). Instructional effects of Concept-Oriented Reading Instruction on motivation for reading information text in middle school. Adolescents' Engagement in Academic Literacy, 155-215.

Jaya, A., \& Marleni, M. (2018). TEACHING READING PROCEDURE TEXT THROUGH CONCEPT ORIENTED READING INSTRUCTION (CORI) TO THE TENTH GRADE STUDENTS OF STATE SENIOR HIGH SCHOOL 13 PALEMBANG. English Community Journal, 2(1), 158-166.

Kalsum, U., Suwarno, B., \& Dharmayana, I. W. (2017). THE EFFECT OF CONCEPT ORIENTED READING INSTRUCTION (CORI) STRATEGY TOWARD STUDENTS'READING COMPREHENSION. JOALL (Journal of Applied Linguistics and Literature), 2(1), 60-71.

Kendeou, P., Van Den Broek, P., Helder, A., \& Karlsson, J. (2014). A cognitive view of reading comprehension: Implications for reading difficulties. Learning Disabilities Research \& Practice, 29(1), 10 16.

Levy, Y., \& Ellis, T. J. (2011). A guide for novice researchers on experimental and quasiexperimental studies in information systems research. Interdisciplinary Journal of Information, Knowledge, and Management, 6(1), 151-161.

Moreillon, J. (2007). Collaborative Stategies for Teaching Reading Comprehension. American Library Association.

Rayner, K., Pollatsek, A., Ashby, J., \& Clifton Jr, C. (2012). Psychology of reading.

Ruddell, M. R. (1997). Teaching content reading and writing. ERIC.

Ruddell, R. B., \& Ruddell, M. R. (2004). Teaching children to read and write. Allyn \& Bacon.

Suryani, H. (2017). Using Concept Oriented Reading Instruction (CORI) to Promote Students' Reading Comprehension. IJER (Indonesian Journal of Educational Research), 2(1), 42-45.

Sustika, Y. (2017). The effect of concept-oriented reading instruction (CORI) on students' reading comprehension at the eight grade of Madrasah Tsanawiyah Negeri Binjai. State Islamic University of North Sumatera.

Verhoeven, L., \& Van Leeuwe, J. (2008). Prediction of the development of reading comprehension: A longitudinal study. Applied Cognitive Psychology: The Official Journal of the Society for Applied Research in Memory and Cognition, 22(3), 407-423.

Wigfield, A. (2004). Motivating reading comprehension: Concept-oriented reading instruction. Routledge.

Wigfield, A., Mason-Singh, A., Ho, A. N., \& Guthrie, J. T. (2014). Intervening to improve children's reading motivation and comprehension: Concept-oriented reading instruction. In Motivational interventions. Emerald Group Publishing Limited. 